ZOOLOGIA 27 (5): 696-702, October, 2010

doi: $10.1590 /$ S1984-46702010000500005

\title{
Immature stages of the butterfly Diaethria clymena janeira (Lepidoptera: Nymphalidae: Biblidinae)
}

\author{
Eduardo P. Barbosa'; Lucas A. Kaminski' \& André V. L. Freitas ${ }^{1,2}$ \\ 1 Departamento de Biologia Animal, Instituto de Biologia, Universidade Estadual de Campinas. Caixa Postal 6109, \\ 13083-970 Campinas, SP, Brazil.E-mail: baku@unicamp.br; ed_1482@yahoo.com.br; lucaskaminski@yahoo.com.br \\ ${ }^{2}$ Corresponding author.
}

\begin{abstract}
The immature stages (egg, larva, and pupa) morphology, larval and oviposition behavior, and host plant of the "eighty-eight" butterfly Diaethria clymena janeira (C. Felder, 1862) are described. Eggs are laid singly under leaf, and have pronounced vertical ribs ending up in a crown. Larvae of early instars construct stick-like frass chains where they rest when not feeding. Late instars are green with reduced body scoli and long branched head scoli. Pupae are entirely green, and pupation occurs on the upper leaf surface. In general, morphology and behavior of immature stages are similar to those of related species in the tribe Callicorini.
\end{abstract}

KEY WORDS. Callicorini; frass chains; host plants; immature behavior; Ulmaceae.

The Biblidinae is a phylogenetically well defined subfamily of nymphalid butterflies (Freitas \& Brown 2004, WaHLBerg et al. 2009), and may be recognized by the presence of a sclerotized postero-ventral plate near the end of the males' abdomen, the hypandrium or "gonostatumen" (MAZA \& TURREnT 1985). Other features of this subfamily are a Vogel's organ at the base of the forewing (a membranous structure with hearing function), which is also found in several other groups of Nymphalidae (L.D. ОтеRо 1990, YACK et al. 2000), and the construction of frass chains (a stick-like structure made by feces and silk) by early instars of most species, a behavioral trait also present in Charaxinae, Cyrestinae, Limenitidinae, and Coeini (Morrel 1954, DeVries 1987, Freitas \& Oliveira 1992).

Currently, seven or eight tribes are recognized in Biblidinae, with Callicorini being the most speciose, with nine genera and more than 70 described species (Harvey 1991, LAmas 2004, Wahlberg et al. 2009). Diaethria Billberg, 1820 is the third most diverse genus in this tribe (12 species) (Lamas 2004), being widely distributed in the Neotropical region, from Mexico to Northern Argentina (D'Abrera 1987). Despite the great number of species in this genus, early stages are known for only three species, two of them from adequate descriptions (MüLleR 1886, Muyshondt 1975, Muyshondt et al. 1976).

Since immature stages are considered a source of important characters for taxonomic and phylogenetic studies (Kitching 1985, Harvey 1991, Penz \& Peggie 2003), and because they can hold information of kinship not available in adults (Penz 1999, Freitas \& Brown 2004, Willmott \& Freitas 2006), detailed descriptions of early stages of any butterfly species are intrinsically relevant and should be reported.

The present paper describes the immature stages of $D$. clymena janeira (C. Felder, 1862) in detail, including information about host plants and larval behavior.

\section{MATERIAL AND METHODS}

Adults and immatures were studied in two localities in the state of São Paulo, Brazil: 1) campus of the Universidade Estadual de Campinas (Unicamp, Campinas, 650 m, 2249'17"S, $\left.47^{\circ} 4^{\prime} 10^{\prime \prime} \mathrm{W}\right), 2$ ) Santa Genebra Forest Reserve (Campinas, 650$\left.700 \mathrm{~m}, 22^{\circ} 49^{\prime} 19^{\prime \prime} \mathrm{S}, 47^{\circ} 6^{\prime} 47^{\prime \prime} \mathrm{W}\right)$. Descriptions of immature stages were mainly based on material collected in 2009-2010 at the Unicamp campus, in a small woodlot $(<0.1 \mathrm{ha})$ of secondary forest planted behind the Departamento de Biologia Animal in the 1970s, and where the host plant, Trema micrantha (Linnaeus) Blume (Ulmaceae), is fairly common.

Leaves bearing eggs were brought to the laboratory, and larvae were reared individually in $500 \mathrm{ml}$ plastic containers that were cleaned daily and replenished with leaves whenever necessary. Data on behavior and development times were taken for all stages. Height and width were measured to ascertain egg size. The larval head capsule size was measured as the distance between the two groups of stemmata; scoli length was also measured (as in FreItAS \& BROWN 2008). Immatures were fixed in Kahle solution (Borror \& DeLong 1971); all adults, preserved larvae, capsules, and pupal skins have been deposited at Unicamp (Museu de Zoologia "Adão José Cardoso", ZUEC, Universidade Estadual de Campinas). 


\section{RESULTS}

\section{Description of the immature stages}

Egg (Figs 1 and 2): average diameter $0.69 \mathrm{~mm}(\mathrm{SD}=0.063$, $\mathrm{n}=8)$; average height $0.63 \mathrm{~mm}(\mathrm{SD}=0.063, \mathrm{n}=8)$. Round, with apex and base flat, light green in the beginning of the development and white near hatching, decorated with 16-17 vertical and 20-22 horizontal ribs, vertical ribs more conspicuous, forming prominent keels, and projecting near the apex to form a "crown". Duration: 4-5 days $(\mathrm{n}=2)$.

First instar (Figs 3 and 9-10): Head capsule width 0.44$0.50 \mathrm{~mm}(\mathrm{n}=3)$. Maximum body length $3.5 \mathrm{~mm}$. Head dark brown, round and smooth, without ornamentation. Body light green with brown areas, smooth, with short dark setae inserted in sclerotized pinacula. Legs brown; prolegs with 12 unisserial crochets in a uniordinal series and a dark lateral plate; anal plate light brown. Head and body chaetotaxy (following STEHR 1987) as in figures 9 and 10, respectively. Duration: four days $(\mathrm{n}=4)$.

Second instar (Fig. 4): head capsule width 0.48-0.63 mm $(\mathrm{n}=5)$. Head scoli length 0.3-0.4 mm $(\mathrm{n}=5)$. Maximum body length $5.5 \mathrm{~mm}$. Head light brown, with a pair of short brown scoli covered with small protuberances on vertex. Body light green with short green scoli with brown setae. Legs, prolegs and anal plate green. Duration: four days $(n=3)$.

Third instar (Fig. 5): head capsule width $0.88 \mathrm{~mm}(\mathrm{n}=4)$. Head scoli length 2.8-3.3 $\mathrm{mm}(\mathrm{n}=4)$. Maximum body length $8.3 \mathrm{~mm}$. Head light brown, with a pair of long scoli on vertex; scoli with two rows of four short spines and a crown of five spines, all bearing long setae. Body entirely green. Legs, prolegs and anal plate green. Duration: 5-6 days $(n=4)$.

Fourth instar (Fig. 6): head capsule width 1.32-1.38 mm $(\mathrm{n}=3)$. Head scoli length 4.8-5.0 $\mathrm{mm}(\mathrm{n}=3)$. Maximum body length $13 \mathrm{~mm}$. Head dark brown, with a pair of long scoli on vertex very similar to previous instar, but with one additional row of four spines. Body light green, with two pairs of thin yellow lines, one subdorsal and the other lateral; body covered with very short green scoli with dark brown spines; the pair of scoli on A10 larger than the scoli on the other segments. Legs, prolegs and anal plate green. Duration: $4-6$ days $(n=4)$.

Fifth (last) instar (Figs 7-8 and 11): head capsule width 2.00-2.75 mm $(\mathrm{n}=3)$. Head scoli length 7.5-8.0 $\mathrm{mm}(\mathrm{n}=3)$. Maximum body length $25 \mathrm{~mm}$. Head and body in all aspects similar to previous instar, except for the abdominal scoli that are more conspicuous in the fifth instar. Prolegs with numerous unisserial crochets in a biordinal series. The yellow stripes disappear in the prepupa, when the larva becomes entirely green. The distribution of body scoli is in figure 11. Duration: seven days $(\mathrm{n}=3)$.

Pupa (Figs 12-14): length $16-17 \mathrm{~mm}(\mathrm{n}=2)$. Entirely green, the abdomen with a lateral yellow stripe and sparse cream dots on dorsal region; a white line bordering wing caps, continuing through thorax and head. General profile elongated, with a conspicuous bump in segment T2; ocular caps short and pointed; abdominal segments mobile. Duration: 8-9 days $(\mathrm{n}=4)$.

\section{Oviposition and behavior}

In the two study sites, the only larval host plant was Trema micrantha. Females lay eggs singly on the lower leaf surface near the petiole. After hatching, the larva ingests the chorion and then moves on to the leaf apex, where it starts to feed on plant tissue. During the initial instars (first to third), larvae feed on the tip of the leaf. Leaving the central vein intact, they construct a frass chain and attach it to the central vein. When not feeding, first and second instars rest with the head oriented away from the petiole, while later instars rest with the head towards the petiole. When disturbed, late instars may assume a defensive posture, raising the anterior segments (Fig. 6), curling and wriggling vigorously (beat reflex) if the disturbance continues. Pupae are seldom observed in the field, since the larvae usually move out of the host plant. Based on reared larvae and one field observation, pupation occurs on the upper surface of the leaf, with the pupa positioned horizontally against the leaf surface.

\section{DISCUSSION}

\section{Host plant use}

The use of Trema micrantha by D. clymena (Cramer, 1775) is unique within the Callicorini, whose members typically use Sapindaceae as host plants (BECCALONI et al. 2008). Additionally, there have been reports of Diaethria clymena meridionalis (H.W. Bates, 1864) using Celtis (Ulmaceae) and species of Euphorbiaceae and Sterculiaceae (Lima 1928, Silva et al. 1968), and D. clymena marchalli (Guérin-Méneville, [1844]) feeding on T. micrantha and on two species of Tiliaceae (DEVRIES 1987, Janzen \& HallwaChs 2010) in Costa Rica. Based on field observations and laboratory experiments of host shifts (unpublished data by the authors), all evidence suggests that the populations of D. clymena in southeastern South America (including D. clymena janeira, Fig. 15) are specialized on T. micrantha. The use of Sapindaceae has never been observed in the region, the records of Euphorbiaceae and Sterculiaceae are probably mistakes, and the use of Celtis needs confirmation. The use of Ulmaceae has only been reported for Diaethria candrena (Godart, [1824]) in southeastern Brazil, besides D. clymena, with all remaining species of Diaethria feeding on Sapindaceae (MuYsHONDT 1975, Muyshondt et al. 1976, DeVries 1987, Beccaloni et al. 2008, Janzen \& Hallwachs 2010).

The use of Sapindaceae as larval host plant is a trait shared by the clade formed by Epiphilini+Callicorini (sensu Freitas \& BRown 2004). Most of the remaining Biblidinae feed on Euphorbiaceae, a plesiomorphic condition in this subfamily, and the switch to Sapindaceae can be considered an important trait in the diversification of the Epiphilini+Callicorini clade (sensu Freitas \& Brown 2004). The few reliable exceptions include the 

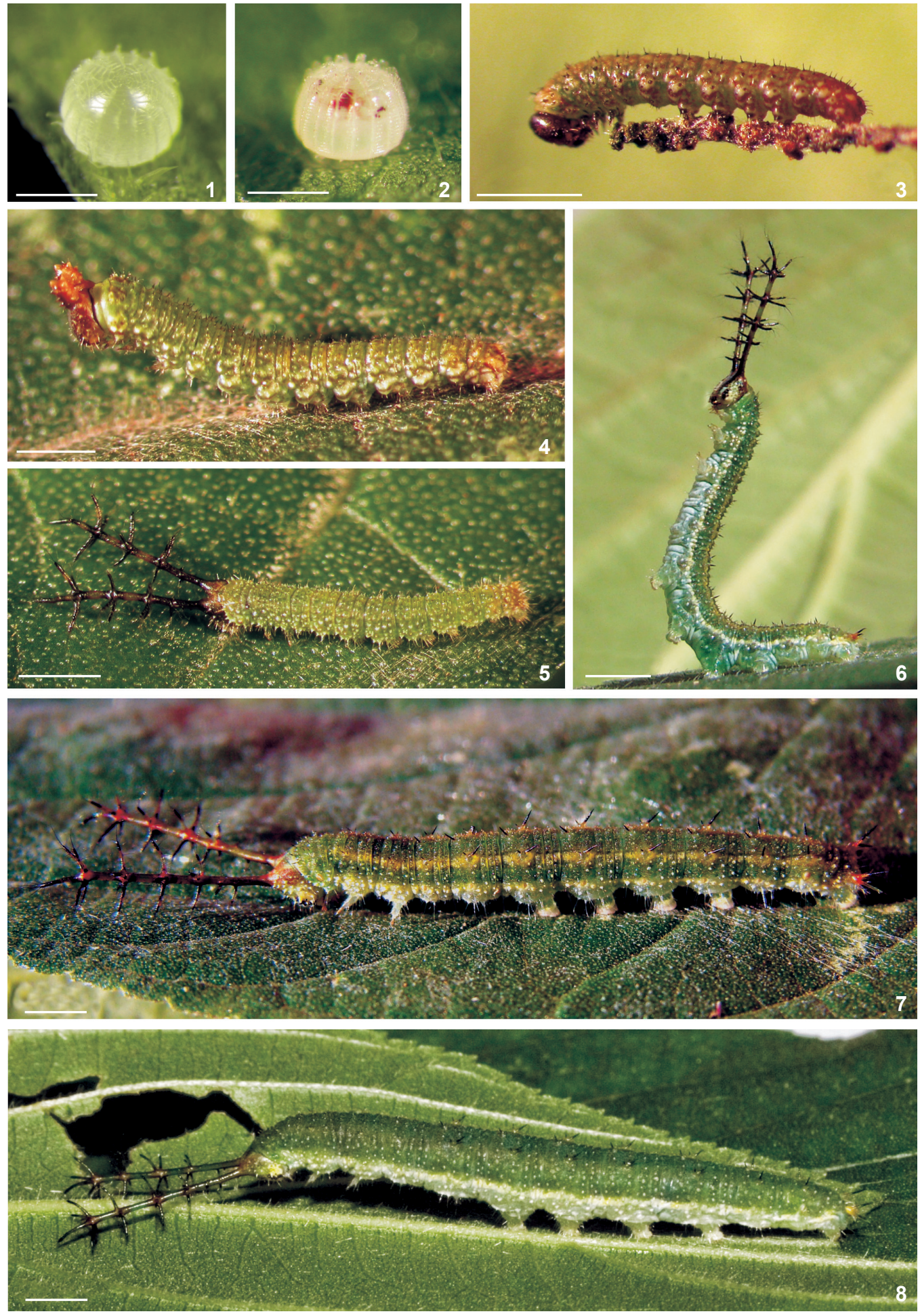

Figures 1-8. Immature stages of Diaethria clymena janeira: (1) newly laid egg, dorsal view; (2) mature egg, lateral view; (3) first instar at the tip of a frass-chain; (4) second instar; (5) third instar; (6) fourth instar in defensive posture; (7) fifth instar, latero-dorsal view; (8) fifth instar, prepupa, lateral view. Scale bars: $1-2=0.5 \mathrm{~mm}, 3-4=1.0 \mathrm{~mm}, 5=1.5 \mathrm{~mm}, 6-8=2.5 \mathrm{~mm}$. 

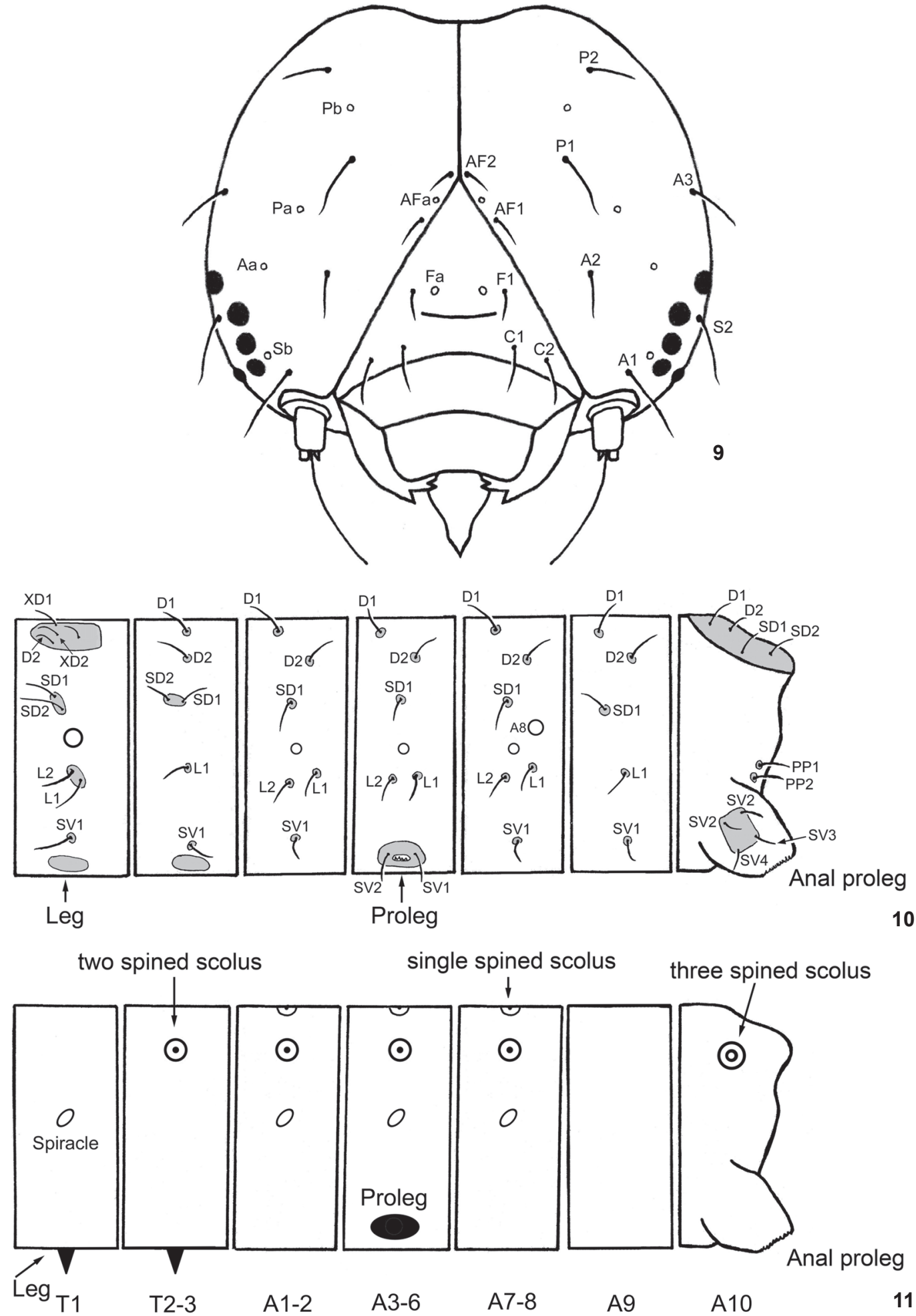

Figures 9-11. Diaethria clymena janeira: (9) head chaetotaxy of first instar; (10-11) larval body diagrams: (10) first instar chaetotaxy; (11) fifth instar scoli distribution. 

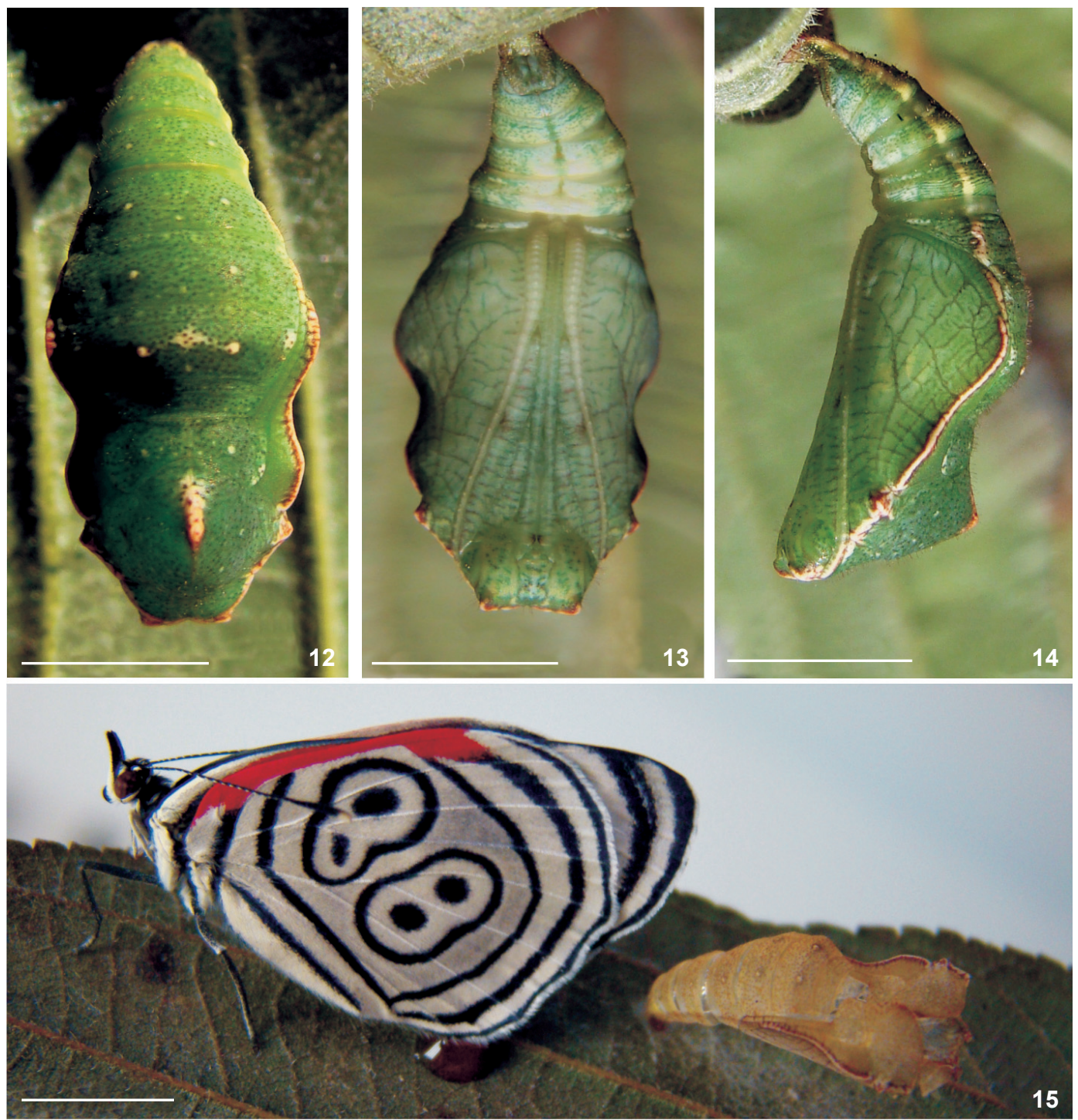

Figures 12-15. Immature stages and adult of Diaethria clymena janeira: (12-14) pupa, dorsal, ventral, and lateral views; (15) newly emerged adult. Scale bars: $0.5 \mathrm{~cm}$.

use of Ulmaceae and Tiliaceae by D. clymena, and the use of Cunoniaceae by two species of Mesotaenia Kirby, 1871 (BECCALONI et al. 2008). The records of Epiphile Doubleday, [1845] and Temenis Hübner, [1819] on Malpighiaceae, Perisama Doubleday, 1849 on Gunneraceae, and Lucinia Hübner, [1823] on Apocynaceae (BECCALONi et al. 2008) need further confirmation.

\section{Morphology of immature stages}

The early stages of D. clymena janeira are identical to those of D. clymena meridionalis from coastal areas of the states of São Paulo and Rio Grande do Sul, Brazil (AVLF and LAK, unpublished data), and are quite similar to those of $D$. clymena marchalii (Guérin-Méneville, [1844]), D. astala (Guérin-Méneville, [1844]) and D. pandama (Doubleday, [1848]) from Central America (Muyshondt 1975, Muyshondt et al. 1976, Janzen \& Hallwachs 2010). Therefore, the following discussion focuses on comparisons within Biblidinae, especially Epiphilini and Callicorini.

The shape of the egg, including the prominent keels forming a crown near the apex, is generally similar to those of other known Epiphilini and Callicorini, including Callicore Hübner, [1818], Temenis Hübner, [1819], Nica Hübner, [1826] and Pyrrhogyra Hübner, [1819]. However, in Callicore and Diaethria the keels are thin; while in the remaining genera they are broad, thus resembling short bumps (MuYshondT 1974a, b, c, d, AVLF and LAK, unpublished data). 
The short setae reported for the first instar is a condition found in most Biblidinae, except in the Biblidini, Eubagini and in the clade of Sea Hayward, $1950+$ Cybdelis Boisduval, 1836 (VAn Son 1979, Freitas et al. 1997). From $3^{\text {rd }}$ to $5^{\text {th }}$ instars, the head capsule with long scoli armed with spines is similar to those found in most Epiphilini and Callicorini, but the scoli are considerably longer in Diaethria, similar to those of Callicore (MülLER 1886, DeVries 1987, L.S. Otero 1990, Teshorigi 2007, Janzen \& Hallwachs 2010). The reduced body scoli in all segments is a condition similar to that observed in some Callicore, Perisama and in Haematera Doubleday, 1849, though it is also observed in Cybdelis and some species of Eunica Hübner, [1819] (Freitas et al. 1997, Teshirogi 2007, AVLF, unpublished). Pupae are quite similar to most Biblidinae, and the general greenish coloration is widespread in the whole subfamily (Freitas et al. 1997, Teshirogi 2007, JANZEN \& HaLLWACHS 2010). The pupation in the upper surface of the leaf is a general trait described for several species in the Epiphilini and Callicorini (MuYsHondT 1974a, b, c, d, 1975).

Detailed descriptions of immatures are of great value in allowing identification of early stages in the field, as well as in providing adequate information to extract characters for taxonomic and phylogenetic studies (Aiello 1984, Freitas \& Brown 2004). Additionally, even though the Neotropical Biblidinae contains more than 260 species, early stages have been described for only a small fraction of species, especially in some speciose genera such as Eunica, Callicore, Perisama and Diaethria (Freitas et al. 1997). Even in the cases where early stages are already known for a particular taxon, additional detailed descriptions are still worthwhile and would be helpful in the identification of stable versus variable traits. In this context, the detailed description of the immature stages of D. clymena janeira should be of use in forthcoming studies within the Biblidinae.

\section{ACKNOWLEDGEMENTS}

We are grateful to: Fosca P.P. Leite, for the use of lab equipment; Marcelo Duarte, for sending pictures of several D. clymena subspecies for comparisons; Carla Penz, Marcelo Duarte, Keith Willmott and one anonymous reviewer, for suggestions on the manuscript. Financial support was provided by Conselho Nacional de Desenvolvimento Científico e Tecnológico (CNPq 140183/2006-0 to LAK, PIBIC fellowship to EPB, CNPq 300282/ 2008-7 to AVLF) and by Fundação de Amparo à Pesquisa do Estado de São Paulo (FAPESP grants \#00/01484-1 and \#04/ 05269-9 to AVLF). This research is part of the BIOTA-FAPESP program (grant \#98/05101-8).

\section{LITERATURE CITED}

Aiello, A. 1984. Adelpha (Nymphalidae): Deception on the wing. Psyche 91: 1-45.

Beccaloni, G.W.; S.K. Hall; A.L. Viloria \& G.S. Robinson. 2008. Catalogue of the hostplants of the Neotropical Butterflies/ Catálogo de las plantas huésped de las mariposas Neotro- picales. In: Monografias Tercer Milenio. Zaragoza, S.E.A., RIBES-CYTED, The Natural History Museum, Instituto Venezolano de Investigaciones Científicas, vol. 8, 536p.

Borror, D.J. \& D.M. DeLong. 1971. An Introduction to the Study of Insects. New York, Holt, Rinehart and Winston, 812p.

D'Abrera, B. 1987. Butterflies of the Neotropical region, part IV, Nymphalidae (Partim). Victoria, Hill House, XV+p. 528678.

DeVries, P.J. 1987. The butterflies of Costa Rica and their natural history. Papilionidae, Pieridae, Nymphalidae. Princeton, Princeton University Press, 327p.

Freitas, A.V.L. \& P.S. Oliveira. 1992. Biology and behavior of the Neotropical butterfly Eunica bechina (Nymphalidae) with special reference to larval defense against ant predation. Journal of Research on the Lepidoptera 31 (1/2): 1-11.

Freitas, A.V.L. \& K.S. Brown Jr. 2004. Phylogeny of the Nymphalidae (Lepidoptera). Systematic Biology 53 (3): 363-383.

Freitas, A.V.L. \& K.S. Brown JR. 2008. Immature stages of Vila emilia (Nymphalidae: Biblidinae). Tropical Lepidoptera Research 18 (2): 74-77.

Freitas, A.V.L.; K.S. Brown Jr \& L.D. Otero. 1997. Juvenile stages of Cybdelis, a key genus uniting the diverse branches of the Eurytelinae (Lepidoptera, Nymphalidae). Tropical Lepidoptera 8: 29-34.

Harvey, D.J. 1991. Higher classification of the Nymphalidae. Appendix B, p. 255-273. In: H.F. Nijhout (Ed.). The development and evolution of butterfly wing patterns. Washington, D.C., Smithsonian Institution Press, 318p.

Janzen, D.H. \& W. Hallwachs. 2010. Dynamic database for an inventory of the macrocaterpillar fauna and its food plants and parasitoids of Area de Conservacion Guanacaste (ACG), northwestern Costa Rica (nn-SRNP-nnnnn voucher codes). Available on line at: http://janzen.sas.upenn.edu [Accessed: 10.VIII.2010]

Kitching, I.J. 1985. Early stages and the classification of the milkweed butterflies (Lepidoptera: Danainae). Zoological Journal of the Linnean Society 85: 1-97.

Lamas, G. 2004. Biblidinae, p. 234-247. In: G. LAMAS (Ed.). Checklist: Part 4A. Hesperioidea-Papilionoidea. In: J.B. Heppner (Ed.). Atlas of Neotropical Lepidoptera. Gainesville, Association for Tropical Lepidoptera, Scientific Publishers, vol. 5A, XXXIV+439p.

LiMA, A.M. DA C. 1928. Segundo catálogo systemático dos insectos que vivem nas plantas do Brasil e ensaio de bibliographia entomológica brasileira. Arquivos da Escola Superior de Agricultura e Medicina Veterinária 8 (1/2): 69-301.

MazA, R.G. De LA \& R.D. Turrent. 1985. Mexican Lepidoptera. Eurytelinae I. Publicaciones especiales. Sociedad Mexicana de Lepidopterología 4: VI+44p.

Morrell, R. 1954. Notes on the larval habits of a group of Nymphalid butterflies. Malayan Nature Journal 8: 157-164. MülLER, W. 1886. Sudamerikanische Nymphalidenraupen: 
Versuch eines naturlichen Systems der Nymphaliden. Zoologischen Jahrbüchern 1: 417-678.

MuyshondT, A. 1974a. Notes on the life cycle and natural history of butterflies of El Salvador. IIA. Epiphile adrasta adrasta (Nymphalidae-Catonephelinae). Journal of the New York Entomological Society 81 (4): 214-223.

Muyshond, A. 1974b. Notes on the life cycle and natural history of butterflies of El Salvador. III.A. Temenis laothoe liberia Fabricius (Nymphalidae - Catonephelinae). Journal of the New York Entomological Society 81 (4): 224-233.

MuyshondT, A. 1974c. Notes on the life cycle and natural history of butterflies of El Salvador. IV.A. Pseudonica flavilla canthara (Nymphalidae - Catonephelinae). Journal of the New York Entomological Society 81 (4): 234-242.

Muyshondt, A. 1974d. Notes on the life cycle and natural history of butterflies of El Salvador. V.A. Pyrrhogyra hypsenor (Nymphalidae - Catonephelinae). Journal of the New York Entomological Society 82 (3): 163-172.

MuYshond, A. 1975. Notes on the life cycle and natural history of butterflies of El Salvador. VI.A. - Diaethria astala Guerin. (Nymphalidae - Callicorinae). Journal of the New York Entomological Society 83 (1): 10-18.

Muyshondt, A.; A. Muyshondt Jr \& P. Muyshondt. 1976. Notas sobre la biología de lepidópteros de El Salvador I. Revista de la Sociedad Mexicana de Lepidopterología 2 (2): 77-90.

OTERo, L.D. 1990. Estudio de algunos caracteres para su uso en la classificación de Eurytelinae (Lepidoptera: Nymphalidae). Boletín de Entomología Venezolana 5: 123-138.

OTERo, L.S. 1990. Butterflies. Beauty and behavior of Brazilian species. Rio de Janeiro, Marigo Comunicação Visual, 128p.

Penz, C.M. 1999. Higher level phylogeny for the passion-vine butterflies (Nymphalidae, Heliconiinae) based on early stage and adult morphology. Zoological Journal of the Linnean Society 127: 277-344.
Penz, C. \& D. Peggie. 2003. Phylogenetic relationships among Heliconiinae genera based on morphology (Lepidoptera: Nymphalidae). Systematic Entomology 28: 451-479.

Silva, A.G. D'A. E; C.R. Gonçalves; D.M. Galvão; A.J.L. Gonçalves; J. Gomes; M. do N. Silva \& L. DE Simoni. 1968. Quarto catálogo dos insetos que vivem nas plantas do Brasil, seus parasitos e predadores. Edição ampliada do " $3^{\circ}$ catálogo dos insetos que vivem nas plantas do Brasil" de autoria do Prof. A. M. da Costa Lima. Parte II. Insetos, hospedeiros e inimigos naturais. Índice de insetos e índice de plantas. Rio de Janeiro, Ministério da Agricultura. 1: XXVII+622p, 2: VIII+265p.

Stehr, F.W. 1987. Order Lepidoptera, p. 288-305. In: F.W. SтенR (Ed.). Immature insects. Dubuque, Kendall/Hunt, vol. 1, $\mathrm{XII}+754 \mathrm{p}$.

Teshirogi, M. 2007. The splendid Biblidinae in the Neotropical region. Butterflies 47: 30-44.

VAN Son, D. 1979. The butterflies of Southern Africa. Part IV. Nymphalidae: Nymphalinae. Pretoria, Transvaal Museum, 286p.

Wahlberg, N.; J. Leneveu; U. Kodandaramaiah; C. Peña; S. Nylin; A.V.L. Freitas \& A.V.Z. Brower. 2009. Nymphalid butterflies diversify following near demise at the Cretaceous/Tertiary boundary. Proceedings of the Royal Society B 276: 42954302. doi: 10.1098/rspb.2009.1303.

Willmott, K.R. \& A.V.L. Freitas. 2006. Higher-level phylogeny of the Ithomiinae (Lepidoptera: Nymphalidae): classification, patterns of larval hostplant colonization and diversification. Cladistics 22: 297-368.

Yack, J.E.; L.D. Otero; J.W. Dawson; A. Surlykke \& J.H. Fullard. 2000. Sound production and hearing in the blue cracker butterfly Hamadryas feronia (Lepidoptera, Nymphalidae) from Venezuela. Journal of Experimental Biology 203: 3689-3702.

Submitted: 25.II.2010; Accepted: 16.IX.2010.

Editorial responsibility: Gabriel L.F. Mejdalani 